\title{
A Primer on Exporting to El Salvador ${ }^{1}$
}

\author{
Christina D. Storz, Timothy G. Taylor, and Gary F. Fairchild ${ }^{2}$
}

\section{Introduction}

Every year the U.S. Department of State publishes extensive Country Commercial Guides for a large number of countries. These guides provide a great deal of information useful to individuals interested in developing export markets either through direct exports or through direct foreign investment. This paper provides an abridged version of the Country Commercial Guide for El Salvador as well as supplemental information of direct relevance to agribusiness firms. It is hoped that the information contained in this report provides a useful starting point for individuals interested in exploring export or investment opportunities in El Salvador.

Note: County Commercial Guides are available for U.S. exporters from the National Trade Data Bank's CD-ROM or via the Internet. Please contact Stat-USA by telephone (1-800) STAT-USA for more information. Country Commercial Guides can be accessed via the World Wide Web at http://www.stat-usa.gov, http://www.state.gov, and http://www.mac.doc.gov. They can also be ordered as a hard copy or on diskette from the National Technical Information Service (NTIS) by telephone (1-800) 553-NTIS. American exporters seeking general export information/assistance and country-specific commercial information should contact the U.S. Department of Commerce, Trade Information Center by telephone (1-800) USA-TRADE; or by fax (202) 482-4473.

\section{Economic and Political Overview}

As a result of more than a decade of systematic economic policy reforms, crowned in 2001 with the introduction of the U.S. dollar as full legal tender, El Salvador has the most open trade and investment environment in Central America, surpassed in Latin America only by Chile and Mexico. The country enjoys excellent macroeconomic stability, low inflation, and falling interest rates. Nonetheless, growth has been slow since 1995, when the boom that followed the 1992 peace accords came to an end.

The government of El Salvador views private investment, both domestic and foreign, and increased trade as crucial to bringing faster growth, stronger job creation, and long-term development. The Salvadorans have taken many steps to assist investors. These include setting up an agency to help investors complete all legal steps for establishing a business, simplifying procedures for processing imports and exports, and eliminating all controls on capital flows. The government has sought free trade agreements with major trading partners and with

1. This is EDIS document FE512, a publication of the Department of Food and Resource Economics, Florida Cooperative Extension Service, Institute of Food and Agricultural Sciences, University of Florida, Gainesville, FL. Published February 2005. Please visit the EDIS website at http://edis.ifas.ufl.edu.

2. Christina D. Storz, Research Assistant; Timothy G. Taylor, Professor; and Gary F. Fairchild, Professor, Department of Food and Resource Economics, Florida Cooperative Extension Service, Institute of Food and Agricultural Sciences, University of Florida, Gainesville, FL. 
other countries viewed as key growth markets. The most significant development in this effort is the negotiations for a U.S.-Central American Free Trade Agreement (CAFTA), which was initiated in January of 2003. The United States is the destination of about $67 \%$ of Salvadoran exports and provides about $50 \%$ of El Salvador's imports. The government of El Salvador sees increased trade with the United States as central for further growth and development.

Dollarized and enjoying the lowest inflation and interest rates in the region, El Salvador has the foundation for solid economic growth. The government forecasted a $3 \%$ growth rate for 2003 , which is higher than $2.1 \%$ achieved in 2002 but still below the $6.1 \%$ annual average achieved during the post-war boom of 1992 to 1995. An important factor in favor of faster growth is the government's continued success in seeking expanded free trade with its principal trading partners. El Salvador has free trade agreements with Chile, the Dominican Republic, Mexico, and Panama.

El Salvador is undergoing an economic transition that offers diverse opportunities for export sales and investment. For more than a decade, the economy has been moving from agriculture to manufacturing. Coffee, long the most important product, has nearly disappeared as an export income earner. The manufacturing, construction, retail, and service sectors have all grown. Clothing assembly (maquila) exports continue to increase despite the slower economic growth in the United States, the main export market. Per capita income has also risen during the last decade. Consumer demand is fueled both by the increase in income and the massive inflow of remittances from Salvadorans living in the United States.

\section{Marketing U.S. Products and Services}

There are a number of factors that should be considered in exporting products to El Salvador. This section provides a brief overview of many critical factors that must be considered.

\section{Establishing a Business}

El Salvador's National Investment Office (ONI) operates a "one-stop" window to help foreign companies and individuals complete the requirements needed to obtain a license to establish a business in El Salvador, whether it is a branch, agency, office, or joint venture. Hiring a local legal representative or attorney to work with ONI is recommended as a way to help ensure that all steps are completed. A brief description of the needed authorizations and licenses follows:

- Obtain authorization for commercial activity and provide proof of required capital to begin operations from the Superintendent of Business and Mercantile Corporations. Must provide proof that the company is legally registered in the United States and that the company has capital in excess of US\$25,000.

- Obtain an income and property clearance and a Value Added Tax collector number from the General Director of Internal Taxes and Ministry of Finance.

- Request a license from the Commerce Registry at the National Registry Center in the Commerce and Industry License Registry Department. All companies operating in El Salvador must prepare their accounting records in Spanish. For issuance of the license, the Registry must approve the Spanish version of the accounting system. The names of the company's board of directors and administrative personnel must be provided to the Commerce Registry.

- Obtain municipal services clearance from the municipality where the company and its facilities will be located and certification that the firm is properly registered in the National Industrial and Commercial Establishments Directory at the General Director of Statistics and Census.

Once the Commerce Registry has issued the company's license, it must be published in a local newspaper. The Salvadoran government must certify the company's accountants and external auditors. 
An environmental permit is required for all activities.

The Foreign Agricultural Service (FAS) of the U.S. Department of Agriculture (USDA) administers the Commodity Credit Corporation (CCC) Export Credit Guarantee Programs (GSM-102/103) for commercial financing of U.S. agricultural exports. Under these programs, the CCC does not provide financing but does guarantees payments due from foreign banks. Two programs underwrite credit extended by the private banking sector in the United States or by the U.S. exporter to approved foreign banks using dollar-denominated, irrevocable letters of credit to pay for food and agricultural products sold to foreign buyers. The Export Credit Guarantee Program (GSM-102) covers credit terms up to three years. The Intermediate Export Credit Guarantee Program (GSM-103) covers credit terms up to 10 years.

The USDA also offers the CCC Supplier Credit Guarantee Program (SCGP) for the Central American region. It covers short-term financing extended directly by U.S. exporters to foreign buyers and requires that the importers sign a promissory note in case of default on the CCC-backed payment guarantee. Information about these programs is available online at http://www.fas.usda.gov/info/factsheets/gsmprog.html

\section{Distribution / Sales Channels}

Large distributors usually import most products, and large department stores import directly from manufacturers or exporters. While the large distributors have well-established networks of buyers, they handle such a wide range of products that they often cannot dedicate the time and resources necessary to promote new or lesser-known products. Many well-known U.S. products are imported via U.S. distributors in El Salvador and not directly from the producer. As a result, many U.S. products gain name recognition before a formal supplier/distributor relationship is set up.Small retailers often travel to the United States to purchase and carry back products themselves.

\section{Agents / Distributors: Finding a Partner}

The use of agents and distributors is the most common way to export products and services to foreign countries and a very effective means to market new products. For El Salvador, one agent for the country is sufficient since commercial activity is concentrated in the capital San Salvador and the size of the country does not usually justify regional agents. An exclusive territorial contract is recommended only when the business relationship has proven to be stable, professional, and profitable for both parties. For first-time partners or new-to-market companies, an authorized distributor or an alternative to exclusive representation is recommended.

\section{Direct Marketing}

Privatization of telecommunications has greatly improved direct marketing and created new target audiences on cable television. The number of cellular phone and Internet users has dramatically increased. Reliable telecommunication services have allowed more use of fax communication features and e-mail. Although the government is making efforts to upgrade its public mail system, the business sector normally uses local private delivery companies. Door-to-door sales by U.S. cosmetics and household products firms, under-the-door-promotional flyers, and direct-from-television sales are increasing. Electronic commerce is still in an early stage. The American Chamber of Commerce helped draft a bill to promote and regulate e-commerce in El Salvador.

\section{Franchising}

While U.S. franchises have been present in El Salvador for at least 30 years, they have only recently begun to accelerate rapidly, with U.S. fast-food franchises as the most successful. A longstanding dispute between a prominent U.S. franchise and its former franchisee suggests that enforcement of franchise contracts in the courts can be difficult, and we urge franchisers to develop their business cautiously based on careful analysis of the business bona fides of their potential franchisees. 


\section{Joint Ventures / Licensing}

Joint ventures involving U.S. and Salvadoran companies must be legally established in a contract signed by both parties. Foreign investments, whether joint venture, direct investment, partnership, branch, or subsidiaries, must be incorporated in El Salvador to operate. Once incorporated and duty registered, the investment receives national treatment.

Licensing is included in the Law for Trademarks and Other Distinctive Signs (approved in 2002), which raises protections for trademarks and distinctive signs to internationally accepted standards and obliges national and foreign firms to register in the Commerce Registry and the Intellectual Property Registry. To have the exclusive right of exploitation of commercial names, trademark, any expression, and/or advertising sign, including patents and industrial designs, an attorney or legal representative must register the trademark at: Registro de Propiadad Intelectual; Centro Nacional de Registros; 1a. Calle Poniente y 43 Ave. Norte No. 2310; San Salvador, El Salvador (telephone 503-260-8000 or 503-260-7916).

Registration fees range from US\$10 to US\$60.

\section{Selling Factors / Techniques}

New consumer products are often introduced at receptions in upscale hotels, together with newspaper and billboard ad campaigns. As competition increases, creative sales promotions such as contests, drawings, and raffles are becoming more relevant. Use of E-Mail and the Internet has made great advances in just the last year. Samples of products are often handed out at supermarkets and department stores. Participation in local exhibits and sponsorship of local events and conferences are common local practices for brand positioning. Shared budget for promotional campaigns and advertising is highly appreciated by the local importer/distributor, and simple things such as the availability of brochures and other promotional materials in Spanish are very helpful for marketing products. American companies interested in finding representatives or distributors to sell their products should look for ways of adding value to the relationship (e.g., increasing sales by supporting local marketing efforts). Each sector has its peculiarities and techniques; therefore the Economic Commercial Section encourages U.S. companies to approach the Embassy for specific information.

\section{Advertising / Trade Promotion}

Advertising in El Salvador is mainly through Television, radio, newspapers, billboards, and brochures. Depending on the target market, nature of the product, purpose of the message, or marketing plan, advertising agencies will recommend the most appropriate media mix.

In terms of mass communication, the country has four VHF commercial television stations. Five newspapers circulate in the country, with an estimated daily circulation of 281,000 . Four of these have Internet versions. The main radio stations are located in the city of San Salvador. There are approximately $200 \mathrm{FM}$ radio stations in the country but only $20 \%$ broadcast nationwide. The American Chamber of Commerce, the Chamber of Commerce and Industry, and the Salvadoran Association of Industry, as well as other trade organizations, circulate monthly and bi-monthly journals that accept advertising.

\section{Sales Service / Customer Support}

With over two million residents in the United States, Salvadorans are familiar with U.S. products. Sellers can get an edge by offering good service and customer support. Consumers and/or end-user purchasing decisions respond differently, depending on the product or sector, but in general they are price oriented, tied to credit conditions and to after-sale service.

\section{Product Pricing}

In general, there are no controls on prices in El Salvador. For imported products, price structure includes import duties and the $13 \%$ value-added tax (VAT) that must be added to the purchase price of all products, including basic food products and medicines. Import tariffs for capital goods are $0 \%$, raw materials range from $0 \%$ to $5 \%$, intermediate goods range from $5 \%$ to $10 \%$, and final goods are charged a maximum of $15 \%$. Textiles, agricultural 
products, vehicles, and a few other non-essential products are charged higher tariffs, ranging from $15 \%$ to $30 \%$.These new tariffs apply to products coming from outside the Central American Common Market. A comparative chart of Central American import duties can be found online at the Central American Economic Integration System's website.

\section{Selling to the Government}

In 2000, El Salvador enacted modern and transparent government procurement and contracting laws, which increased the efficiency and transparency in public-sector purchases and contracting procedures and helped to eliminate corruption. A summary of the law is available at the U.S. Embassy's Economic Commercial Section.

For small government purchases, sellers should contact the procurement office in each ministry or autonomous institution, consult postings on the web pages of each institution, or go online at http://www.servicios.gob.sv for general information. Government tenders received by the U.S. Embassy are placed on the U.S. Department of Commerce's National Trade Data Bank or online Electronic Bulletin Board such as "Foreign Government Tenders", or in the "Business Development" publication of the Inter-American Development Bank. While a World Trade Organization (WTO) member, El Salvador has not signed the government procurement agreement.

\section{Need for a Local Attorney}

In El Salvador, as in other countries, finding the right partner is important for success. For a nominal fee, the Economic Commercial Section of the U.S. Embassy in El Salvador offers a range of services to help U.S. companies find potential partners, agents, or distributors. The local lawyer plays a critical role in providing in-depth analysis of the legal consequences of contracts or agreements with local partners and other crucial issues. The attorney is also useful to U.S. companies wishing to participate in government tenders. As legal representative, the lawyer can obtain bidding documents and forward them to the company in the United States. While the Embassy Economic Commercial section cannot recommend a specific attorney, it does provide a list of prominent lawyers in different business areas who can be employed to assist foreign companies.

\section{Agribusiness Industry Prospects}

\section{Wheat}

Wheat is El Salvador's biggest U.S. agricultural commodity import. Most of the wheat processed by Salvadoran mills comes from the United States, although Canadian and Former Soviet Union (FSU) wheat have become very competitive in recent years. Average annual imports of U.S. wheat are 240,000 metric tonnes (MT). In 2002, U.S. wheat imports totaled US\$23.9 million.

\section{Corn}

Since the 1960s, El Salvador has been an important market for U.S. yellow corn, used almost exclusively by the poultry and animal feed industries. Annual imports of yellow corn from the U.S. average around 200,000 MT, covering virtually $100 \%$ of local demand.

\section{Soybean Meal}

El Salvador does not produce soybean meal, so all soybean meal must be imported. The main users are the poultry, pork and livestock sectors, which use the product for feed. Commercial trade is growing at a rapid rate due to the high demand for poultry products. In 2002, soybean meal imports reached US\$23.4 million. El Salvador's poultry industry is the most developed in the region and is quickly increasing production to supply demand by other Central American countries, particularly Honduras. In addition, growth in the fast-food chain market has spurred the consumption of poultry in El Salvador.

\section{Consumer-Oriented Foods / Beverages}

Opportunities for increased sales of consumer oriented foods/beverages and edible fishery products are most notable in the retail sector. The main reason is the rapid expansion of the supermarket industry in this market. In 1995, there were 57 supermarket stores in El Salvador. By the end of 2003, this number was expected to reach 150 nationwide. Supermarkets currently have $40 \%$ of the food retail market. Supermarket growth in working-class areas 
and smaller cities outside the capital of San Salvador is impressive. Consumers are switching from the traditional open-air markets and mom-and-pop stores to the convenience of U.S. style supermarkets. In 2002, consumer food imports from all countries reached US\$372 million. American consumer-oriented product imports were US $\$ 33.1$ million in 2002, but the Salvadoran market may be significantly larger than shown by U.S. export data. A large portion of El Salvador's consumer-oriented food product imports that come through Guatemala's Santo Tomas port are tallied by local customs officials as Guatemalan imports. Of these imports, the best high-value product prospects are processed fruits and vegetables, breakfast cereals, meat sausages, dairy products, snacks (including candies and chocolates), cookies, wine, and ramen style soups.

\section{Rice}

El Salvador's local demand for rice is estimated at 115,000 MT of rough rice. Local production only covers $22 \%$ of local demand. The Salvadoran Rice Millers Association (ASALBAR) has estimated that El Salvador will need to import approximately 72,000 MT of rough rice to satisfy demand. The United States is the main supplier of rice to the Salvadoran market. Traditionally, El Salvador imports rough rice to keep rice mills operating throughout the year. However, small quantities of imported milled rice have recently reached local supermarket chains to fulfill upscale consumer demand. El Salvador has officially abolished the use of a price band mechanism for assessing import duties for basic grains. Import tariffs for rice are now assessed according to a supply deficit quota that is established every marketing year by the Ministry of Agriculture (MAG). This quota is estimated by MAG and is based on the deficit in supply once local production and demand have been calculated. Under this quota, rice millers can import at $0 \%$ duty. Once demand has been satisfied, all imports are assessed a $40 \%$ duty for both rough and milled rice.

\section{Cotton}

Cotton production in El Salvador, after having completely vanished in the mid-1980s, restarted at a low scale in 1998, with a production of 4,000 MT. Cotton consumption has increased as a result of growth in the maquila sector and was expected to reach 28,312 MT in 2003. The country produced less than 1,000 MT in 2002 and imported the rest. The United States supplies virtually all of El Salvador's cotton import needs. Total cotton imports from the United States amounted to US\$14.5 million in 2002. Local textile companies attribute this to high quality standards and delivery reliability. Recent CAFTA negotiations could have a positive impact on cotton consumption if Salvadoran textile exporters can obtain greater access to the U.S. market.

\section{Trade Regulations and Standards}

\section{Trade Barriers}

El Salvador uses the CACM's Central American Import Tariff, which contains the nomenclature for the official classification of goods for the Central American Tariff System (SAC), the import duty rates, and the rules for application. The SAC is based on the Harmonized Commodity Description and Coding System (HS). Currently, all Salvadoran imports originating within the CACM enjoy a zero tariff, except roasted and unroasted coffee, sugarcane, ethyl alcohol and distilled alcoholic beverages, and petroleum products.

Tariffs for goods from outside the CACM include capital goods $(0 \%)$, raw materials ( $0 \%$ to $5 \%$ ), intermediate goods (5\% to $10 \%$ ), and final goods (15\%). Clothing, dairy and meat products, vehicles, and a few other non-essential products (e.g., alcoholic beverages) are charged higher tariffs (15\% to $40 \%$ ). El Salvador's average tariff rate is $7.4 \%$.

El Salvador maintains import tariff quotas for certain agricultural products; some products can only be imported when the domestic supply is insufficient.

\section{Customs Valuation}

El Salvador has taken steps to simplify customs procedures and has been implementing the WTO Customs Valuation Agreement since March 2002.

The Central American Uniform Customs Code (CAUCA III) procedures are in force in El Salvador. CAUCA III modernizes regional customs by implementing uniformed documents, allowing electronic transmission of customs information and 
permitting electronic prepayment of charges, tariffs, and taxes. The Central American countries have agreed to the application of a single manual for customs procedures. Its application began during the first quarter of 2003 as a pilot project involving El Salvador and Guatemala.

El Salvador has also implemented the "Teledespacho" system in which goods can be presented without the use of a custom broker. With the Teledespacho system, the importer/exporter is electronically linked to the Central Customs Service and can present and process all his documents from his office.

The Central America Integrated and Peripheral Customs Project now being implemented will allow customs clearance for several Central American countries to be done at a single customs point of entry facility.

The amount set forth in the commercial invoice is used for tax purposes. If there is doubt about the accuracy of the stated price, Customs assesses its own value.

In general, every Customs declaration should contain at least the following information: the requested customs regime, particulars of the dispatcher or consignee, particulars of the applicant or his representative, type of transport, cargo manifest number, number of the corresponding transport document, country or countries of origin and provenance of the goods, description of the goods, tariff classification of the goods and their trade description, customs value of the goods, and the applicable duties and taxes.

\section{Standards}

El Salvador's key legislation on standardization, metrology, verification, and certification is the Law for the National Science and Technology Council (CONACYT) and the WTO Agreement on Technical Barriers to Trade (WTO-TBT Agreement). There are two types of standards in Salvadoran legislation: Mandatory Salvadoran Standards (NSO) and Recommended Salvadoran standards (NSR). NSOs include the standards regulating the International System of Units. NSRs are concerned with materials, procedures, products, and services not covered by an NSO. El Salvador is applying 52 NSOs (most of which fall into the category of food technology). A certificate of NSO consistency is not required for imports into El Salvador.

\section{Labeling Requirements}

The following requirements are included in the Consumer Protection Law:

- Retailers must have the price of the product either on the packaging or in a visible place.

- Products that are sold by weight or volume or any other measure must have the weight, volume, or an exact measure of its content on the label.

- For pharmaceuticals, the list of ingredients, expiration date, dosage, contraindications, risks involved when used, residual toxic effects, etc. as established by the Ministry of Public Health must be printed on the label.

- Labels on frozen and canned foods must include an expiration date.

\section{Temporary Entry Provisions}

Customs may authorize temporary entry of foreign merchandise with temporary or partial suspension of duties for specific purposes under the condition that they are re-exported within the time authorized and without any modification. A bond must be presented as the guarantee that the temporarily imported goods will be re-exported within the time authorized. Temporary entry of goods for transformation, manufacture, or repair is granted under laws that regulate free trade zones.

\section{Import Controls}

Agricultural products that are either prohibited or restricted include coffee trees and coffee seeds for planting.

Importers of fresh produce, livestock, and food products should check with the Ministry of Agriculture or the U.S. Department of Agriculture office at the U.S. Embassy in El Salvador for the latest phytosanitary regulations. Generally, El 
Salvador's phytosanitary regulations are transparent and scientifically based. However, sanitary regulations are clearly used as a tool to keep poultry from being imported into the country and have been applied to other products in isolated cases. El Salvador is a member of the Organismo Internacional Regional de Sanidad Agropecuaria (OIRSA), a regional zoo/phytosanitary organization based in San Salvador.

Imports are also subject to internal taxes. These include a $13 \%$ value-added tax (VAT) and various selective taxes on products such as alcoholic beverages, carbonated beverages and cigarettes.

In most cases Customs does not require import licenses. Imported vegetables or animals do require a license from the Ministry of Agriculture (MAG) to certify that the goods meet local health and sanitary regulations. Documents needed for processing imported goods through Customs include:

- Import license (if animal, vegetable, or firearms).

- Commercial invoice.

- Bill of lading, airway bill or carta de poder.

When imports come from the Central American Common Market region the only document required is the Customs Form (Formulario Aduanero).

\section{Export Controls}

El Salvador's iguana export industry is regulated by the provisions of the Convention on International Trade in Endangered Species (CITES). In 2000, El Salvador's shrimp industry was certified as complying with U.S. government standards for use of turtle excluder devices (TEDS). Salvadoran tuna exports to the United States have been embargoed since 1997 because of lack of certification for fishing practices protecting dolphins.

\section{Free Trade Zones / Warehouses}

El Salvador currently has 17 free trade zones and more than 200 individual factories that enjoy free zone status. El Salvador's free trade zones are the following: San Bartolo, El Progreso Industrial Park,
Zona Franca El Pedregal, Export Salva Free Zone, San Marcos Free Zone, American Industrial Park, Zona Franca Internacional, Zona Franca Santa Lucía, LIDO Free Zone, Miramar Free Zone, Zona Franca 10, Zona Franca Santa Tecla, Zona Franca Santa Ana, Zona Franca, Zona Franca Santo Tomas, Zona Franca Pipil, and Zona Franca Calvo Conservas.

\section{Membership in Free Trade Agreements}

In January of 2003, a CAFTA was created between the United States and El Salvador, which is El Salvador's most important free trade arrangement. The United States accounts for more than 50\% of El Salvador's trade. The U.S.-El Salvador FTA is expected to significantly reduce barriers to trade and investment.

Other trade agreements to which El Salvador is a member include the Central America-Chile FTA, the Central America-Panama FTA, the Central America-Dominican Republic FTA, the Northern Triangle (El Salvador, Guatemala, Honduras)-Mexico FTA, and the General Treaty for Central American Integration created Central American Common Market (CACM). The Central American countries and Canada are also negotiating a free trade agreement.

El Salvador participates in the Free Trade Area of the Americas (FTAA) negotiating process and is a beneficiary of the tariff preferences of the Caribbean Basin Initiative and the Generalized System of Preferences. It also belongs to the WTO.

\section{Investment Climate in Brief}

- The government of El Salvador views foreign investment as crucial for economic growth and development and has taken numerous steps in recent years to improve the investment climate.

- The 1999 Investment Law grants equal treatment to foreign and domestic investors and allows foreign investors to freely establish businesses in El Salvador.

- There are restrictions on land ownership. No single natural or legal person, Salvadoran or foreign, can own more than 245 hectares (605 acres). 
- The 1998 Free Trade Zones Law is designed to attract investment in a wide range of activities. A Salvadoran partner is not needed to operate in a free zone.

- Since 1993, El Salvador has had a modern IPR law that has been crucial for protecting foreign investors' intellectual property rights (IPR).

- Monetary Integration Law made the U.S. dollar legal tender alongside the Salvadoran colon and fixed the colon exchange rate at 8.75 per dollar. The law mandates banks to keep all accounts in dollars. The dollar has almost completely replaced the colon, which is now rarely used, although in many places prices are still listed in both colones and dollars.

- There are no restrictions on transferring funds associated with investment out of the country. Foreign businesses can freely remit or reinvest profits, repatriate capital, and bring in capital for additional investment.

- According to El Salvador's 1983 Constitution, expropriation can proceed for reasons of public utility or social interest, and indemnification can take place either before or after the fact. There are no recent cases of expropriation.

- Article 15 of the 1999 Investment Law states that disputes between foreign investors and the government will be submitted for arbitration to the International Center for Settlement of Investment Disputes (ICSID), a World Bank affiliated organization. While foreign investors can seek redress of commercial disputes with Salvadoran companies through El Salvador's courts, investors may find that seeking resolution of problems through the slow-moving domestic legal system can be costly and unproductive.

- El Salvador's Investment Law does not require investors to export specific amounts, transfer technology, incorporate set levels of local content, or fulfill other performance criteria. Foreign investors and domestic firms are eligible for the same export incentives. Exports of goods and services pay zero value-added tax.
- Foreign citizens and private companies can freely establish businesses in El Salvador. The only exception for this is in some cases involving small business.

- Private property, both movable and real estate, is recognized and protected in El Salvador. Companies that plan to buy land or other real estate are advised to get a thorough search of the property's title prior to purchase.

- The laws and policies of El Salvador are relatively transparent and generally foster competition. Bureaucratic procedures have improved in recent years and are relatively streamlined for foreign investors.

- El Salvador's 12-year civil war ended in 1992 with a peace agreement. Although general levels of crime are high and are of concern to the business community, there has been no political violence aimed at foreign investors, their businesses, or their property.

- Soliciting, offering, or accepting a bribe is a criminal act in El Salvador. There have been credible complaints about judicial corruption.

- The United States and El Salvador signed a bilateral investment treaty in March of 1999, which addresses issues such as national treatment for foreign investors, transfers, expropriation, investment disputes, and tax policies. The United States has ratified the treaty, but El Salvador has not. The two countries also have a trade and investment council (TIC) framework agreement and are working on a tax information exchange agreement.

- The Overseas Private Investment Corporation (OPIC) has a bilateral agreement with $\mathrm{El}$ Salvador. OPIC has approved insurance coverage for several projects in El Salvador.

- El Salvador has a labor force of approximately 2.6 million people. Salvadoran labor is perceived as hard working and trainable. The general educational level is low, which may pose problems for investors needing skilled, educated labor. 
- There are no foreign exchange controls in El Salvador.

\section{Business Customs}

\section{Travel Advisory and Visas}

The Department of State warns U.S. citizens to exercise caution when traveling to El Salvador because of the high crime rate. For additional general or specific travel information, please contact the Bureau of Consular Affairs, Office of Overseas Citizen Services (CA/OCS) at 888-407-4747 (from overseas at 317-472-2328); or the El Salvador Desk, U.S. Department of State, Tel. (202) 647-3505.The U.S. Department of State offers e-mail safety information updates. Also, the Travel Advisory Service of the U.S. Department of State can provide information in recorded and fax form for any travel warnings on traveling to foreign countries. For recorded information contact Tel:(202) 647-5225.To receive a facsimile, call (202) 647-3732.

A valid passport and either a visa or a tourist card is required to visit El Salvador. Tourist cards, which cost US\$10 and are valid for 30 days, may be obtained prior to departure at Salvadoran consulates, major airlines servicing El Salvador, or at the El Salvador International Airport on arrival. If you plan to remain longer, visas are provided at the Embassy of El Salvador in Washington, D.C. or at the Salvadoran consulates in New York, Long Island, Los Angeles, San Francisco, Santa Ana, Chicago, New Orleans, Louisiana, Boston, Dallas, Houston, Miami, and San Juan. For more information, visit online at http://www.elsalvador.org.

When departing from El Salvador, an exit tax of US\$28 must be paid at the International Airport.

\section{Business Infracstructure}

Salvadoran business relationships and meetings are, at first, formal. A suit and tie are appropriate for most business meetings. Expect to shake hands before and after your meeting, and do not use a person's first name until a relationship has been solidified. Salvadorans commonly use titles such as Licenciado (meaning a college graduate), Ingeniero (engineering graduate), or Doctor (used both for physicians and lawyers). These are followed by the person's last name. While English is widely spoken in business circles and by educated Salvadorans, interpreters can be hired.

El Salvador tends to be very much a business card society and it is important on first meeting someone to exchange business cards. It would be a good idea to have a supply of business cards printed in Spanish.

Breakfast meetings are common and begin about 7:30 a.m. Lunches and dinners can become lengthy affairs (two to three hours), so do not plan too tight a schedule around them. Dinners start late by U.S. standards, frequently at 8:00 p.m. or 9:00 p.m. Lunch is usually at 12:30 p.m. Working hours in the private sector usually are from 8:30 a.m. to 5:30 p.m. and in the government sector from 8:00 a.m. to 4:00p.m.

Visitors commonly drive rental cars and a U.S. driver's license is valid for 60 days. Accommodations in El Salvador vary from deluxe hotels to inexpensive guesthouses. International and U.S. fast-food restaurants are common in the country.

\section{Useful Web Sites}

\section{EL SALVADOR:}

- US Embassy Economic Commercial Section http://sansalvador.usembassy.gov

- American Chamber of Commerce http://www.amchamsal.com/index-en.htm

- Central American Economic Integration System http://www.sicanet.org.sv

- LANIC-El Salvador http://lanic.utexas.edu/la/ca/salvador

- Ministry of Agriculture (MAG) http://www.mag.gob.sv

\section{UNITED STATES:}

- USDA Foreign Agricultural Service http://www.fas.usda.gov 
- US Export Programs Guide

http://infoserv2.ita.doc.gov/ticwebsite/tic.nsf/

AF34FA880278BDD5825690D00656C6F/

F69FDCF72B7713B58525691900746F18?Open

Document

- Internet Guide to Trade Leads

http://infoserv2.ita.doc/gov/ticwebsite/tic.nsf/

504ca249c786e20f85256284006da7ab/

ef7db94aef24919885266470049c1cd?OpenDocu

ment

- US Trade Finance Resources

http://infoserv2.ita.doc.gov/ticwebsite/tic.nsf/

AF34FA880278BDD5825690D00656C6F/

F69FDCF72B7713B58525691900746F18?Open

Document

- Basic Guide to Exporting

http://www.unzco.com/basicguide/index.html

\section{HEMISPHERIC:}

- Hemispheric Guide on Customs Procedures http://alca-ftaa.iadb.org/hgcp_eng.htm

- Hemispheric Trade and Tariff Database http://alca-ftaa.iadb.org/eng/ngmadb_e.htm 